UDC 57.024

LBC 28.073

\title{
MODELLING OF CHRONIC STRESS IN MALE RATS SUBJECTED TO PROLONGED ISOLATION
}

\author{
Yulia D. Ivanova \\ Volgograd State University, Volgograd, Russian Federation \\ Mikhail V. Maltsev \\ Volgograd State University, Volgograd, Russian Federation
}

Alexander V. Kuzubov

Volgograd State Medical University, Volgograd, Russian Federation

Natalya A. Mohamed-Amin

Volgograd State Medical University, Volgograd, Russian Federation

\begin{abstract}
Artificially created social isolation in rodents models a form of chronic stress that causes neurodegenerative changes in the brain and subsequent behavioral changes. The aim of this study was to simulate chronic stress in male rats by social isolation and to determine how chronic stress affects the behavioral and sexual responses of rats. During the simulation of chronic stress, rats were divided into two groups: experimental one, where laboratory animals were kept in separate cells for 10 weeks, and control one, where laboratory animals were kept under normal conditions. Subsequently, a clinical examination of each rat, behavioral tests ("Open Field", "Forced Swimming of Porsolt", "Raised Cruciate Maze") and a study of male sexual behavior were carried out to detect changes in behavioral and sexual responses of the animals. The obtained results of behavioral tests and sexual behavior claim marked changes in behavioral and sexual reactions in the experimental group of animals (high $<$ emotional reactivity, reduced orientation and research reactions, high sexual activity and increased aggression against females). Thus, the authors conclude on successful modelling of chronic stress through social isolation. This model can be used at the deeper study and development of methods of neuropsychiatric disorders therapy.

Key words: social isolation, behavioral tests, sexual behavior, chronic stress, rats, modelling.

Citation. Ivanova Yu.D., Maltsev M.V., Kuzubov A.V., Mohamed-Amin N.A. Modelling of Chronic Stress in Male Rats Subjected to Prolonged Isolation. Prirodnye sistemy i resursy [Natural Systems and Resources], 2021, vol. 11, no. 1, pp. 12-19. DOI: https://doi.org/10.15688/nsr.jvolsu.2021.1.2

УДК 57.024

ББК 28.073

\section{МОДЕЛИРОВАНИЕ ХРОНИЧЕСКОГО СТРЕССА У КРЫС САМЦОВ,} ПОДВЕРГНУТЫХ ДЛИТЕЛЬНОЙ ИЗОЛЯЦИИ
\end{abstract}

\author{
Юлия Дмитриевна Иванова \\ Волгоградский государственный университет, г. Волгоград, Российская Федерация \\ Михаил Васильевич Мальцев \\ Волгоградский государственный университет, г. Волгоград, Российская Федерация
}

Александр Васильевич Кузубов

Волгоградский государственный медицинский университет, г. Волгоград, Российская Федерация 
Моделирование хронического стресса у крыс самцов, подвергнутых длительной изоляции

\section{Наталья Алексеевна Мохамед-Амин}

Волгоградский государственный медицинский университет, г. Волгоград, Российская Федерация

Аннотация. Искусственно созданная социальная изоляция у грызунов моделирует форму хронического стресса, который вызывает нейродегенеративные изменения в головном мозге и следующие за этим поведенческие изменения. Целью данного исследования являлось моделирование хронического стресса у крыс самцов путем социальной изоляции и определение того, как хронический стресс влияет на поведенческие и половые реакции крыс. В ходе моделирования хронического стресса, крыс разделили на две группы: опытная, где лабораторных животных содержали в отдельных клетках, в течение 10 недель и контрольная, где лабораторные животные содержались в обычных условиях. В дальнейшем проводили клинический осмотр каждой крысы, поведенческие тесты («Открытое поле», «Принудительное плавание Порсолта», «Приподнятый крестообразный лабиринт») и исследование полового поведения самцов, для обнаружения изменений в поведенческих и половых реакциях животных. Полученные результаты поведенческих тестов и полового поведения утверждают о выраженных изменениях поведенческих и половых реакциях у опытной группы животных (высокая эмоциональная реактивность, сниженная ориентировочно-исследовательскую реакции, высокая половая активность и повышенная агрессия в отношении самок). Таким образом, можно говорит об успешном моделировании хронического стресса путем социальной изоляции. Данная модель может использоваться при более глубоком изучении и разработке методов терапии нервно психических расстройств.

Ключевые слова: социальная изоляция, поведенческие тесты, половое поведение, хронический стресс, крысы, моделирование.

Цитирование. Иванова Ю. Д., Мальцев М. В., Кузубов А. В., Мохамед-Амин Н. А. Моделирование хронического стресса у крыс самцов, подвергнутых длительной изоляции // Природные системы и ресурсы. - 2021. - Т. 11, № 1. - С. 12-19. -DOI: https://doi.org/10.15688/nsr.jvolsu.2021.1.2

\section{Введение}

Хронический стресс, вызванный социальной изоляцией, является важной частью патогенеза мозговой активности, который отражается в явных поведенческих нарушениях. Для лучшего понимания этиологии депрессии и тревожного расстройства разработки новых, надежных моделей для дальнейшего использования в терапии, в качестве тест - систем, необходимо использовать лабораторных животных [4].

Существует несколько методик приводящих к хроническому, физическому или психосоциальному стрессу, которые моделируют нарушение, как нормальных поведенческих реакций, так и структуры мозга. И поскольку психические расстройства у людей могут быть связаны со снижением социального взаимодействия с окружающим миром, интерес к разработке таких моделей хронического стресса растет $[1 ; 5]$.

Изучение последствий хронического стресса на крысах предполагает набор определенных поведенческих тестов. Использование таких тестов как «Открытое поле», «Экстраполяционное избавление», «Принудительное плавание Порсолта» и «Половое поведение» позволяет оценить изменения поведенческих реакций, нарушения памяти, локомоторной и исследовательской активностей $[2 ; 3]$.

Таким образом, целью нашего исследования стало моделирование хронического стресса у крыс самцов, изучение их поведенческих реакций и репродуктивной функции.

\section{Материал и методы}

Животные. Беспородные белые крысы - самцы, массой от 242 г, в числе 24 особей, разделенные на 2 группы, опыт и контроль. Контроль содержали в нормальных условиях, опыт содержали по 1 клетке на 1 особь, соблюдая условие социальной изоляции.

Экспериментальное моделирование. Крысы были разделены на две группы: контроль и опытная. Опытные животные содержались в отдельных клетках, в изоляции от других, а контрольная группа по 4 особи на одну клетку, то есть в нормальных для них условиях. И в течение 3 месяцев находились под наблюдением.

Клинический осмотр. Осмотр состояния здоровья животных проводился визуально 1 раз в 2 недели. Проводилась оценка: массы тела, состояния шерстного покрова, поведен- 


\section{ЭКОЛОГИя И БИОЛОГИЯ}

ческих реакций и реакцию на присутствие экспериментатора.

Тест «Открытое поле». Крысу помещали в центр камеры хвостом к экспериментатору и наблюдали за её поведением в течение 3 минут. В тесте регистрировались показатели: латентный период выхода из центра поля, число пересеченных квадратов на периферии, число пересеченных ярко-освещённых квадратов, количество вертикальных стоек - пристеночных и свободных, количество заглядываний в отверстия, количество уринаций и дефекаций, число актов кратковременного груминга. По окончанию заданного времени (3 минут) животное возвращали в клетку.

Тест «Принудительное плавание Порсолта». Данное тестирование выполнялось в два этапа: на первом этапе интактные животные помещали на 15 минут в прозрачный плексигласовый цилиндр заполненный водой, второй этап проводили через 24 часа, где животных вновь помещали в емкость с водой при тех же условиях, что и в первый день. Регистрировали следующие показатели: латентный период иммобилизации, общее время нахождения крысы в состоянии иммобилизации, продолжительность активного плавания, продолжительность пассивного плавания и количество прыжков из воды. По окончанию заданного времени, животное возвращали в клетку.

Тест «Приподнятый крестообразный лабиринт». Тестируемое животное помещали на центральную площадку лабиринта головой к открытому рукаву и в течение 3 минут вели наблюдение за ним. В тесте регистрировались: время пребывания животных на центральной площадке, в открытых и закрытых рукавах, количество стоек в закрытых и открытых рукавах, число свешиваний с открытых рукавов и количество заходов в центральную зону, открытые и закрытые рукава. По окончании заданного времени животное возвращали в клетку.

Половое поведение. Крысу - самца извлекли из клетки и поместили в центральное поле установки. По истечении 5 минут адаптационного периода подсадили на центральное поле установки эстрирующую крысу - самку. В момент первого эмоционально- го подхода испытуемого самца к интактной самке зафиксировали время латентного периода. Помимо этого, велось наблюдение за поведением экспериментального животного, регистрируя показатели: Количество «эмоциональных» подходов к сексуальному стимулу; Суммарная продолжительность эмоциональных подходов к партнеру - время (c); Количество аногенитальных обнюхиваний; Аутогруминг; Аллогруминг; Количество садок без интромиссии; Количество садок с интромиссией; Количество копуляций. После завершения наблюдения извлекли животных из установки и поместили в клетки.

Статистическая обработка результатов. Статистическая обработка и вычисление $t$ - критерия Стьюдента проводилась посредством программного пакета «Excel».

\section{Результаты и их обсуждения}

Клинический осмотр. По итогам клинического осмотра у опытной группы животных были замечены ухудшение состояния шерстяного покрова. Прирост массы тела у животных опытной группы был на $35 \%(p<0,05)$ достоверно выше, чем у животных контрольной группы (см. табл. 1 и рис. 1).

Тест «Открытое поле». По результатам «открытого поля» у опытной группы наблюдалось увеличение показателей латентного периода выхода из центра на $70 \%$ $(p<0,05)$ и числа актов дефекации на $50 \%$ $(p<0,05)$, по сравнению с контрольной группой (см. рис. 2 и 3), иначе говоря, наблюдалось изменение показателей эмоциональной реактивности животных. Тенденция увеличения обнаружена и у показателя пересеченных квадратов, характеризующего ориентировочно-исследовательскую реакцию животного опытной группы животных, по отношению к контролю, которая была на $30 \%$ больше $(p<0,05)$. Показатели груминга и обнюхивания у обеих групп различались не достоверно $(p>0,05)$ (см. рис. 2). Следует отметить, что опытная группа животных во время тестирования ни разу не пересекала центр, стараясь держаться ближе к стенке, что говорит о возможности влияния социальной изоляции на исследовательскую и эмоциональные активности животных в целом. 
Моделирование хронического стресса у крыс самцов, подвергнутых длительной изоляции

Таблица 1

Разница масс за три месяца исследования

\begin{tabular}{|c|c|c|c|c|c|c|c|c|c|c|c|}
\hline $\begin{array}{c}\text { Кон- } \\
\text { троль } \\
\end{array}$ & $\begin{array}{l}1 \text { не- } \\
\text { деля }\end{array}$ & $\begin{array}{l}2 \text { не- } \\
\text { деля } \\
\end{array}$ & $\begin{array}{l}3 \text { не- } \\
\text { деля }\end{array}$ & $\begin{array}{l}4 \text { не- } \\
\text { деля } \\
\end{array}$ & $\begin{array}{l}5 \text { не- } \\
\text { деля } \\
\end{array}$ & $\begin{array}{l}6 \text { не- } \\
\text { деля }\end{array}$ & $\begin{array}{l}7 \text { не- } \\
\text { деля } \\
\end{array}$ & $\begin{array}{l}8 \text { не- } \\
\text { деля } \\
\end{array}$ & $\begin{array}{l}9 \text { не- } \\
\text { деля } \\
\end{array}$ & $\begin{array}{c}10 \text { не- } \\
\text { деля } \\
\end{array}$ & $\begin{array}{l}\text { Раз- } \\
\text { ница }\end{array}$ \\
\hline 9 & 287 & 299 & 308 & 321 & 334 & 346 & 354 & 365 & 373 & 385 & $25 \%$ \\
\hline 10 & 297 & 314 & 330 & 349 & 367 & 359 & 371 & 384 & 395 & 410 & $27 \%$ \\
\hline 1 & 278 & 287 & 300 & 312 & 325 & 338 & 351 & 364 & 377 & 389 & $28 \%$ \\
\hline 3 & 256 & 267 & 275 & 289 & 307 & 318 & 330 & 334 & 345 & 364 & $29 \%$ \\
\hline 12 & 276 & 291 & 303 & 315 & 331 & 345 & 358 & 370 & 382 & 391 & $29 \%$ \\
\hline 11 & 269 & 278 & 296 & 310 & 324 & 339 & 353 & 365 & 378 & 387 & $30 \%$ \\
\hline 15 & 287 & 300 & 314 & 326 & 341 & 359 & 367 & 382 & 398 & 410 & $30 \%$ \\
\hline 4 & 287 & 303 & 321 & 345 & 363 & 378 & 387 & 403 & 418 & 412 & $30 \%$ \\
\hline 13 & 287 & 303 & 316 & 337 & 354 & 365 & 378 & 389 & 402 & 413 & $30 \%$ \\
\hline 7 & 315 & 331 & 349 & 367 & 385 & 406 & 410 & 430 & 433 & 450 & $30 \%$ \\
\hline 5 & 252 & 263 & 277 & 291 & 300 & 314 & 330 & 335 & 368 & 376 & $32 \%$ \\
\hline 6 & 254 & 269 & 287 & 305 & 324 & 342 & 361 & 376 & 387 & 394 & $35 \%$ \\
\hline Опыт & $\begin{array}{l}1 \text { не- } \\
\text { деля }\end{array}$ & $\begin{array}{l}2 \text { не- } \\
\text { деля } \\
\end{array}$ & $\begin{array}{l}3 \text { не- } \\
\text { деля }\end{array}$ & $\begin{array}{l}4 \text { не- } \\
\text { деля }\end{array}$ & $\begin{array}{l}5 \text { не-- } \\
\text { деля } \\
\end{array}$ & $\begin{array}{l}6 \text { не-- } \\
\text { деля } \\
\end{array}$ & $\begin{array}{l}7 \text { не- } \\
\text { деля } \\
\end{array}$ & $\begin{array}{l}8 \text { не- } \\
\text { деля } \\
\end{array}$ & $\begin{array}{l}9 \text { не- } \\
\text { деля }\end{array}$ & $\begin{array}{c}10 \text { не- } \\
\text { деля } \\
\end{array}$ & $\begin{array}{l}\text { Рa3- } \\
\text { ница }\end{array}$ \\
\hline 33 & 300 & 318 & 341 & 368 & 385 & 402 & 425 & 453 & 465 & 478 & $38 \%$ \\
\hline 18 & 280 & 303 & 318 & 341 & 364 & 387 & 409 & 423 & 441 & 453 & $38 \%$ \\
\hline 39 & 284 & 315 & 337 & 366 & 389 & 403 & 432 & 448 & 465 & 472 & $40 \%$ \\
\hline 35 & 268 & 287 & 319 & 346 & 368 & 385 & 397 & 412 & 430 & 443 & $40 \%$ \\
\hline 3 & 258 & 273 & 298 & 304 & 328 & 350 & 383 & 409 & 415 & 429 & $40 \%$ \\
\hline 11 & 262 & 276 & 300 & 326 & 349 & 361 & 387 & 404 & 425 & 433 & $40 \%$ \\
\hline 24 & 265 & 276 & 310 & 329 & 346 & 361 & 375 & 398 & 422 & 436 & $40 \%$ \\
\hline 1 & 270 & 286 & 310 & 332 & 354 & 378 & 405 & 429 & 450 & 461 & $41 \%$ \\
\hline 43 & 276 & 309 & 332 & 350 & 373 & 387 & 408 & 433 & 449 & 463 & $41 \%$ \\
\hline 10 & 272 & 280 & 302 & 321 & 343 & 366 & 387 & 421 & 448 & 466 & $42 \%$ \\
\hline 25 & 259 & 275 & 306 & 323 & 345 & 362 & 376 & 402 & 423 & 447 & $42 \%$ \\
\hline 2 & 242 & 256 & 270 & 289 & 311 & 337 & 365 & 384 & 405 & 414 & $42 \%$ \\
\hline
\end{tabular}

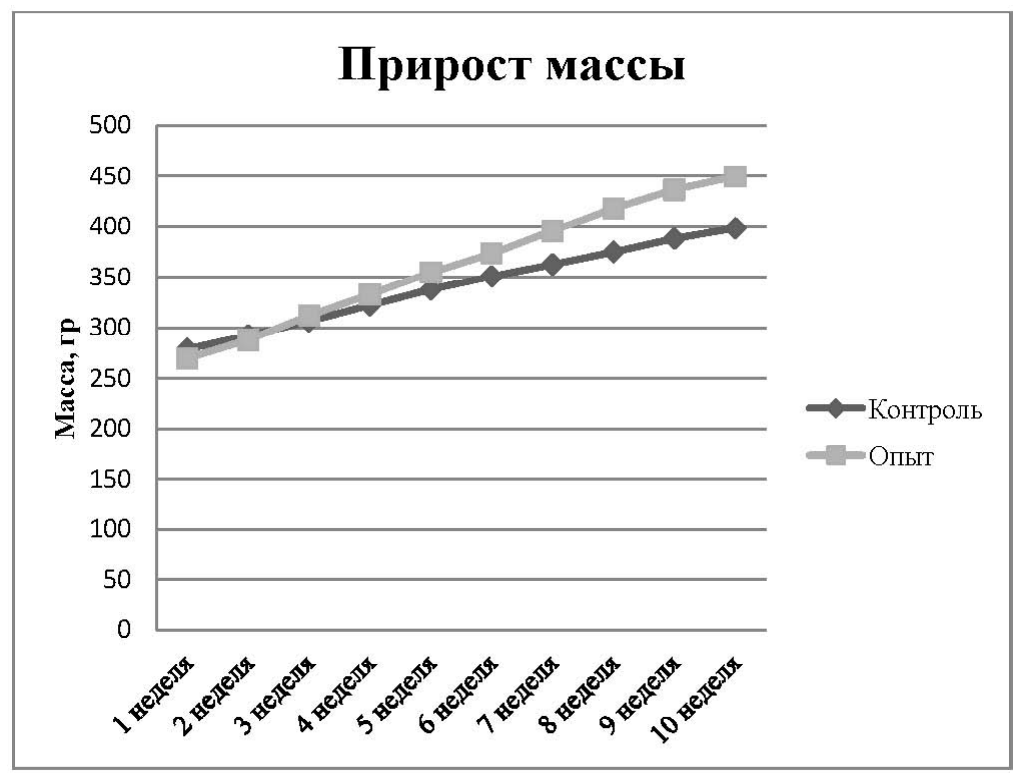

Рис. 1. Сравнение прироста коэффициента масс 


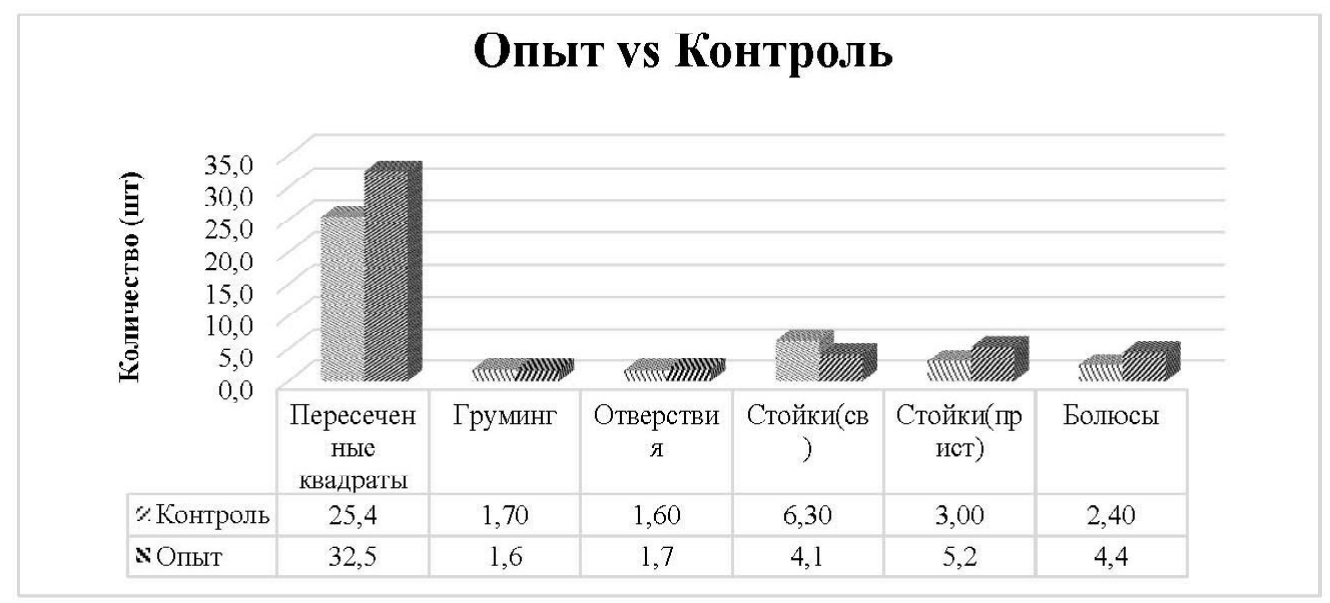

Рис. 2. Средняя разница между группами по тесту «Открытое поле»

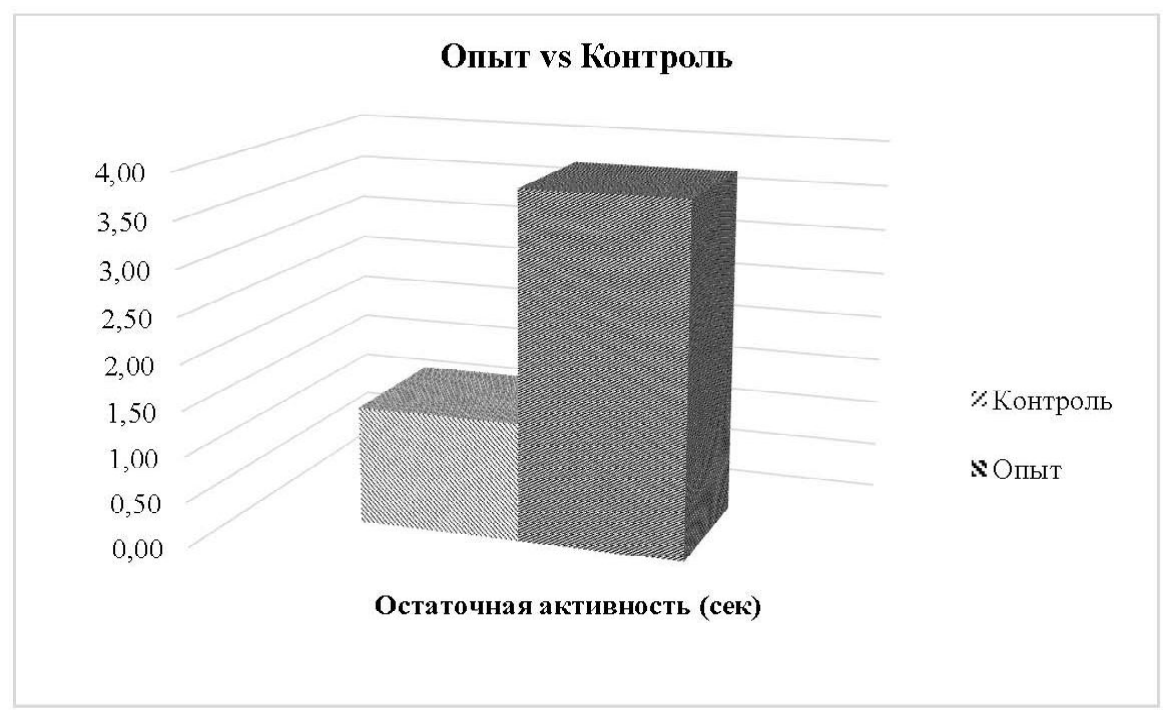

Рис. 3. Среднее значение латентного периода выхода из центра

Тест «Принудительное плавание Порсолта». В результате тестирования обнаружено увеличение времени активного плавания и попыток активного сопротивления на $40 \%(p<0,05)$, характеризующихся увеличением количества прыжков животных опытной группы на $50 \%(p<0,05)$, по сравнению с контрольной группой, что свидетельствует о высокой эмоциональной реактивности животных опытной группы (см. рис. 4).

Тест «Приподнятый крестообразный лабиринт». По итогам данного тестирования был выявлен повышенный уровень тревожности у животных опытной группы. Не достоверно изменились показатели: предпочтение закрытого рукава на $38 \%$, избегание открытого рукава на $44 \%$, боязнь высоты на $45 \%$. Помимо этого, характерно наличие низких показателей стоек и свешиваний на $50 \%$ $(p<0,05)$ (см. рис. 5 и 6). Заметна также разница в предпочтениях: животные опытной группы находились в закрытом рукаве среднем дольше на $25 \%(p>0,05)$, чем животные контрольной группы, а в открытом рукаве ситуация противоположная и в среднем опытная группа там проводила меньше на $15 \%(p>0,05)$ времени, нежели контроль. 
Моделирование хронического стресса у крыс самцов, подвергнутых длительной изоляции

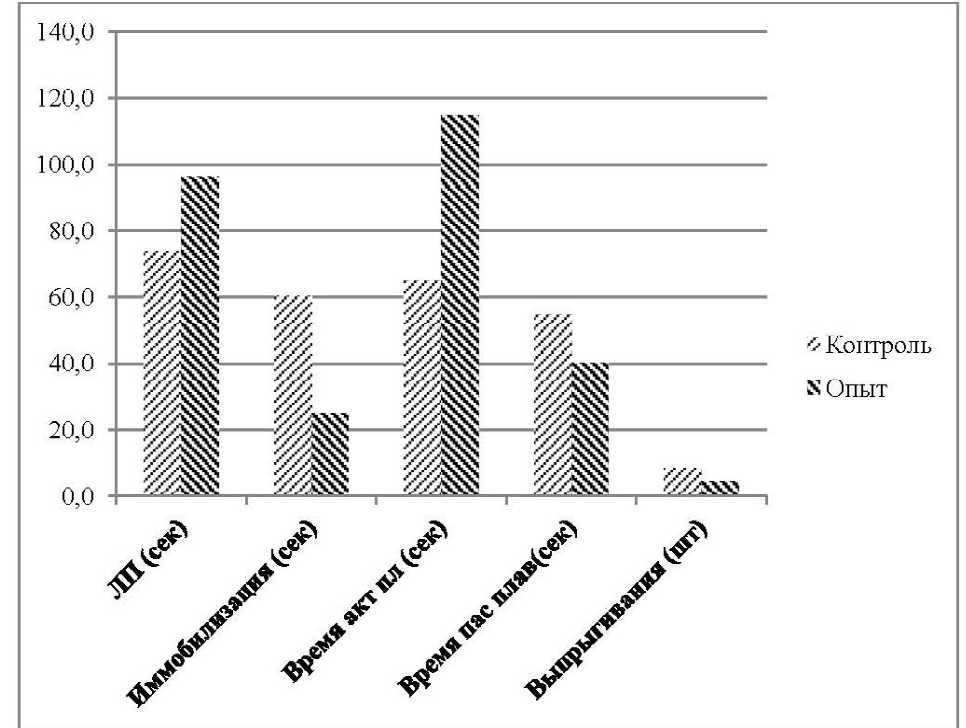

Рис. 4. Результаты теста «Принудительное плавание Порсолта»

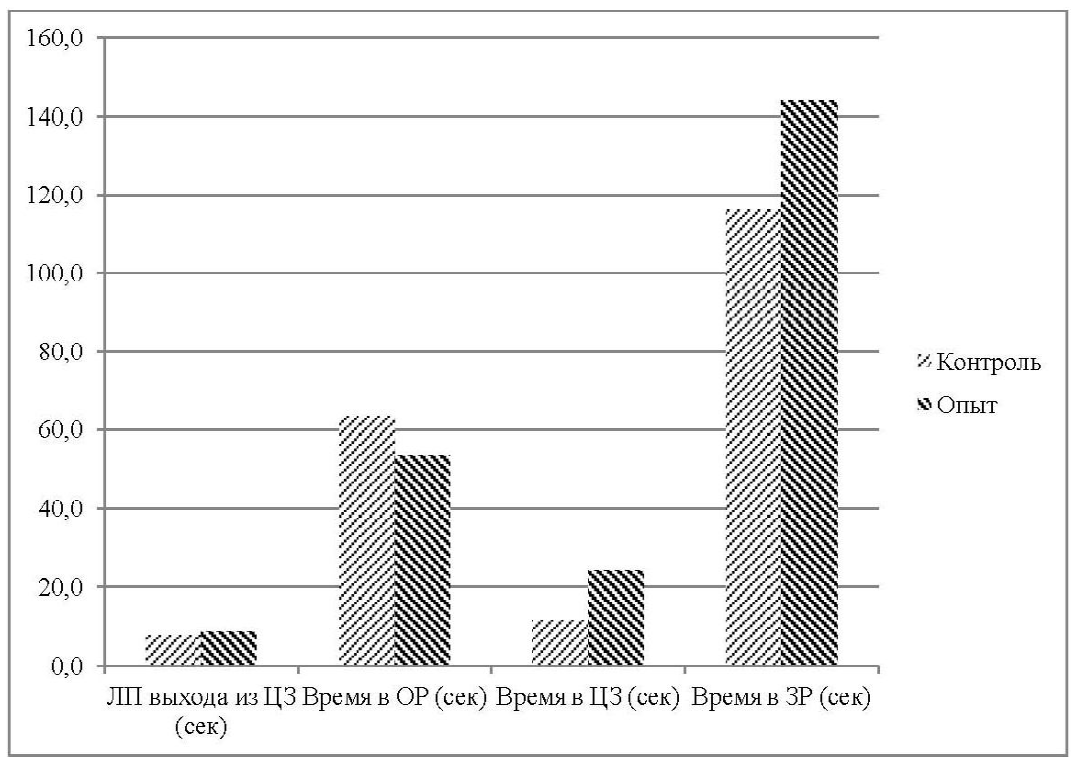

Рис. 5. Показатели времени, проведенного в открытом (ОР), в закрытом рукаве (ЗР) и в центральной зоне (ЦЗ)

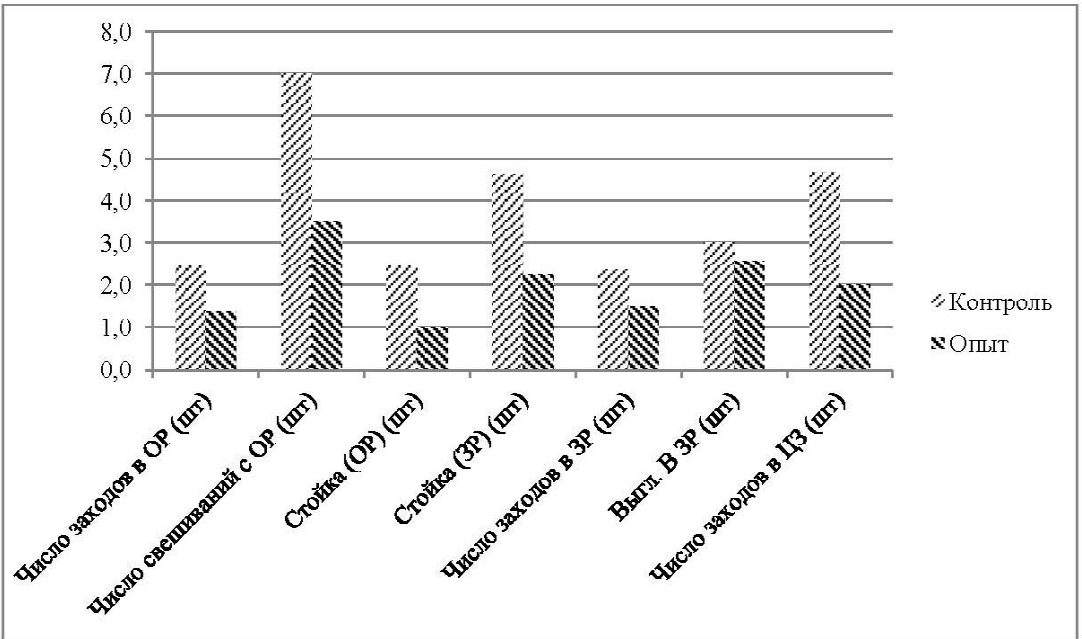

Рис. 6. Показатели исследовательской активности 


\section{ЭКОЛОГИя И БИОЛОГИЯ}

Половое поведение. По результатам изучения полового поведения можно сделать вывод, что опытная группа животных имела более высокий, по сравнению с контрольной группой, уровень половой активности (выше на $25 \%$, $p<0,05)$. Однако стоит отметить агрессивность самцов опытной группы, которые во время эмоционального подхода часто проявляли агрессию в отношении самок (кусали) (см. табл. 2).

\section{Заключение}

Было проведено моделирование хронического стресса у крыс и изучены изменения поведенческих реакций и репродуктивной функции. По результатам вышеописанных тестов можно говорить о наличии ярко выраженного тревожного и депрессивного состояний у животных опытной группы, что говорит об успешности моделирования хронического стресса у крыс путем социальной изоляции:

- данные клинического осмотра показывают неутвердительное состояние шерстяного покрова и лишний вес у опытной группы, по сравнению с контролем;

- результаты тестов «Открытого поля», «Принудительное плавание Порсолта» и «Приподнятый крестообразный лабиринт» позволяют сделать вывод о высокой эмоциональной реактивности опытной группы животных и сниженной ориентировочно-исследовательскую реакции, по сравнению с контролем;

- итоги проведения исследования полового поведения показали высокий уровень половой активности и агрессивное поведение у опытной группы, в отличие от контроля.

\section{СПИСОК ЛИТЕРАТУРЫ}

1. Амстиславская, Т. Г. Половая активация самцов крыс: поведение и гормональный ответ / Т. Г. Амстиславская, К. В. Осипов // Сибирский научный медицинский журнал. - 2003. - № 3. - С. 112-114.
2. Геворкян, В. С. Современные исследования воздействия различных стресс-факторов на крыс и мышей / В. С. Геворкян, И. С. Геворкян // Электронное научное издание Альманах Пространство и Время. - 2017. - Т. 15, № 1.

3. Изучение влияния производного аминоэтанола на когнитивные функции лабораторных животных / И. А. Титович [и др.] // Биомедицина. - 2017. №3. - C. 102-110.

4. Ieraci, A. Social isolation stress induces anxiousdepressive-like behavior and alterations of neuroplasticityrelated genes in adult male mice / A. Ieraci, A. Mallei, M. Popoli // Neural plasticity. - 2016. - Vol. 2016. - P. 113. -DOI: https://doi.org/10.1155/2016/6212983.

5. Toth, I. Animal models of social avoidance and social fear / I. Toth, I. D. Neumann // Cell and tissue research. - 2013. - Vol. 354, № 1. - P. 107-118. DOI: https://doi.org/10.1007/s00441-013-1636-4.

\section{REFERENCES}

1. Amstislavskaya T.G., Osipov K.V. Polovaya aktivaciya samcov krys: povedenie i gormonal'nyj otvet [Sexual arousal in the male rat: behavioral and hormonal response]. The Siberian Scientific Medical Journal, 2003, no. 3, pp. 112-114.

2. Gevorkyan V.S., Gevorkyan I.S. Sovremennye issledovaniya vozdejstviya razlichnyh stress-faktorov na krys i myshej [Modern studies of different stressors effects on rats and mice]. Elektronnoe nauchnoe izdanie Al'manah Prostranstvo i Vremya [E-Almanac Space and Time], 2017, vol. 15, no. 1.

3. Titovich I.A. et al. Izuchenie vliyaniya proizvodnogo aminoetanola na kognitivnye funkcii laboratornyh zhivotnyh [The study of a novel diethylaminoethanol derivative cognitive function in laboratory animals]. Journal Biomed, 2017, no. 3, pp. 102-110.

4. Ieraci A., Mallei A., Popoli M. Social isolation stress induces anxious-depressive-like behavior and alterations of neuroplasticity-related genes in adult male mice. Neural plasticity, 2016, vol. 2016, pp. 1-13. DOI: https://doi.org/10.1155/2016/6212983.

5. Toth I., Neumann I.D. Animal models of social avoidance and social fear. Cell and tissue research, 2013, vol. 354, no. 1, pp. 107-118. DOI: https://doi.org/ 10.1007/s00441-013-1636-4.

Таблийа 2

Результаты полового поведения

\begin{tabular}{|c|c|c|c|c|c|c|c|c|c|}
\hline $\begin{array}{c}\text { Среднее } \\
\text { значение }\end{array}$ & $\begin{array}{c}\text { Латентный } \\
\text { период }\end{array}$ & $\begin{array}{c}\text { Время } \\
\text { до первой } \\
\text { садки } \\
\end{array}$ & $\begin{array}{c}\text { Садки без } \\
\text { интромиссии }\end{array}$ & $\begin{array}{r}\text { Садки с } \\
\text { интро- } \\
\text { миссией } \\
\end{array}$ & $\begin{array}{l}\text { Общая продолжи- } \\
\text { тельность эмоцио- } \\
\text { нального подхода }\end{array}$ & $\begin{array}{c}\text { Количество } \\
\text { эмоциональ- } \\
\text { ных подходов } \\
\end{array}$ & $\begin{array}{c}\text { Аногени- } \\
\text { тальное об- } \\
\text { нюхивание } \\
\end{array}$ & $\begin{array}{l}\text { Auto- } \\
\text { gruming }\end{array}$ & $\begin{array}{l}\text { Allo- } \\
\text { gruming }\end{array}$ \\
\hline Контроль & 22,7 & 81,7 & 4,3 & 2 & 406,7 & 33,7 & 21,3 & 53 & 8,3 \\
\hline Опыт & 6,7 & 59 & 5,7 & 0 & 367,3 & 52,3 & 32,7 & 44,7 & 1,7 \\
\hline Разница & $70 \%$ & $28 \%$ & $25 \%$ & $100 \%$ & $25 \%$ & $35 \%$ & $35 \%$ & $16 \%$ & $80 \%$ \\
\hline
\end{tabular}


Моделирование хронического стресса у крыс самцов, подвергнутых длительной изоляции

\section{Information About the Authors}

Yulia D. Ivanova, Master Student, Department of Biology, Volgograd State University, Prosp. Universitetsky, 100, 400062 Volgograd, Russian Federation, jullianna777@yandex.ru

Mikhail V. Maltsev, Candidate of Sciences (Biology), Associate Professor, Department of Biology, Volgograd State University, Prosp. Universitetsky, 100, 400062 Volgograd, Russian Federation, maltsev@volsu.ru

Alexander V. Kuzubov, Candidate for a Degree, Toxicology Laboratory, Scientific Center for Innovative Medicines with Pilot Production, Volgograd State Medical University, Novorossiyskaya St, 39, 400087 Volgograd, Russian Federation, eakuzubova@mail.ru

Natalya A. Mohamed-Amin, Candidate of Sciences (Medicine), Senior Lecturer, Department of Biology, Volgograd State Medical University, Rokossovskogo St, 1G, 400131 Volgograd, Russian Federation, bahar-23@yandex.ru

\section{Информация об авторах}

Юлия Дмитриевна Иванова, студент 2-го курса магистратуры кафедры биологии, Волгоградский государственный университет, просп. Университетский, 100, 400062 г. Волгоград, Российская Федерация, jullianna777@yandex.ru

Михаил Васильевич Мальцев, кандидат биологических наук, доцент кафедры биологии, Волгоградский государственный университет, просп. Университетский, 100, 400062 г. Волгоград, Российская Федерация, maltsev@volsu.ru

Александр Васильевич Кузубов, соискатель лаборатории токсикологии Научного центра инновационных лекарственных средств с опытно-промышленным производством, Волгоградский государственный медицинский университет, ул. Новороссийская, 39, 400087 г. Волгоград, Российская Федерация, eakuzubova@mail.ru

Наталья Алексеевна Мохамед-Амин, кандидат медицинских наук, старший преподаватель кафедры биологии, Волгоградский государственный медицинский университет, ул. Рокоссовского, 1Г, 400131 г. Волгоград, Российская Федерация, bahar-23@yandex.ru 